\title{
The Valve Timing Optimization of the Diesel Engine Based on Response Surface Methodology
}

\author{
Jun Li, Lei Ji, Yangjiao Xu \& Jinli Xie
}

Chongqing Jiaotong University, Chongqing, China

Correspondence: Jun Li, Mechantronics and Automotive Engineering, Chongqing Jiaotong University, 400074, Chongqing, China. Tel: 86-138-8390-1379. E-mail: xuyangjiao1986@gmail.com

Received: October 30, 2013 Accepted: November 11, $2013 \quad$ Available online: December 5, 2013

doi:10.11114/set.v1i1.262 URL: http://dx.doi.org/10.11114/set.v1i1.262

\begin{abstract}
To study the effect of valve timing on the diesel engine performance, the simulation model of diesel engine was established with AVL BOOST and its accuracy was proved. The volumetric efficiency is one of the important indicators to evaluate engine performance. The volumetric efficiency as optimization objective and valve timing were optimized and discussed by using Box-Behnken test method and the response surface methodology. Optimization result shows that volumetric efficiency of the diesel engine can been increased by $6.42 \%$ under rated speed.
\end{abstract}

Keywords: response surface methodology, valve timing, volumetric Efficiency

\section{Introduction}

The simulation of the engine's working process has become an important method to the research and development (Lei et al., 2011; Rakopoulos et al., 2004; Razmjooei et al., 2010). It is established the one-dimensional simulation model of the working process of diesel engine by AVL BOOST. And the simulation model is validated by speed characteristic. Then the influence of valve timing on the volumetric efficiency of diesel engine is analyzed and optimized in using the response surface methodology to obtain the optimal valve timing and the volumetric efficiency of engine. The volumetric efficiency can be increased $6.42 \%$ under the rated speed.

\section{Model Establishment}

\subsection{The Model Establishment}

The 4-cylinder, 4-stroke and turbocharged diesel engine was used in bench test. The basic parameter of the diesel engine is shown in Tab.1. The simulation model was established, shown in Fig.1. The Vibe 2 Zone heat release model and Woschni1978 heat transfer model was used (Liu, 2011).

Table 1. The main parameters of diesel engine

\begin{tabular}{cc}
\hline Basic parameters & Parameter values \\
\hline Compression Ratio & 18 \\
Bore $\times$ Stoke $(\mathrm{mm})$ & $75 \times 80$ \\
Rated Power $(\mathrm{kW})$ & 65 \\
Rated Speed $(r / \mathrm{min})$ & 4500 \\
Intake Valve Close $(\mathrm{IVO})\left({ }^{\circ} \mathrm{CA}\right)$ & 63 \\
Intake Valve Open $(\mathrm{IVC})\left({ }^{\circ} \mathrm{CA}\right)$ & 101 \\
Exhaust Valve Open $(\mathrm{EVO})\left({ }^{\circ} \mathrm{CA}\right)$ & 105 \\
Exhaust Valve Close $(\mathrm{EVC})\left({ }^{\circ} \mathrm{CA}\right)$ & 63 \\
\hline
\end{tabular}

2.2 Validation of the Simulation Model

The simulation model of diesel engine was verified from calculated results and experimental results, shown in Fig.2. 


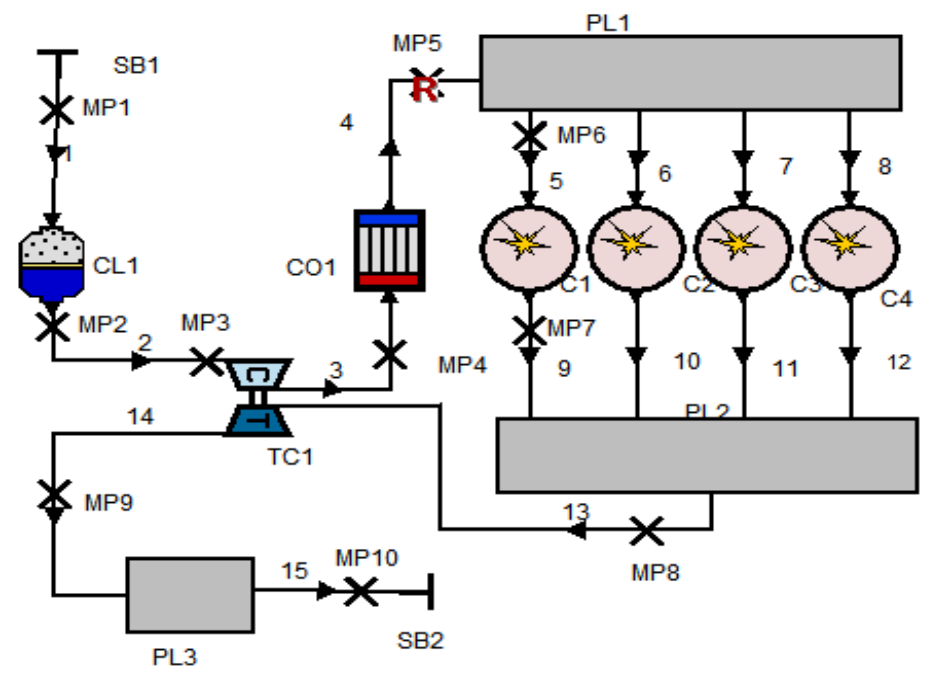

Figure 1. Simulation model of diesel engine

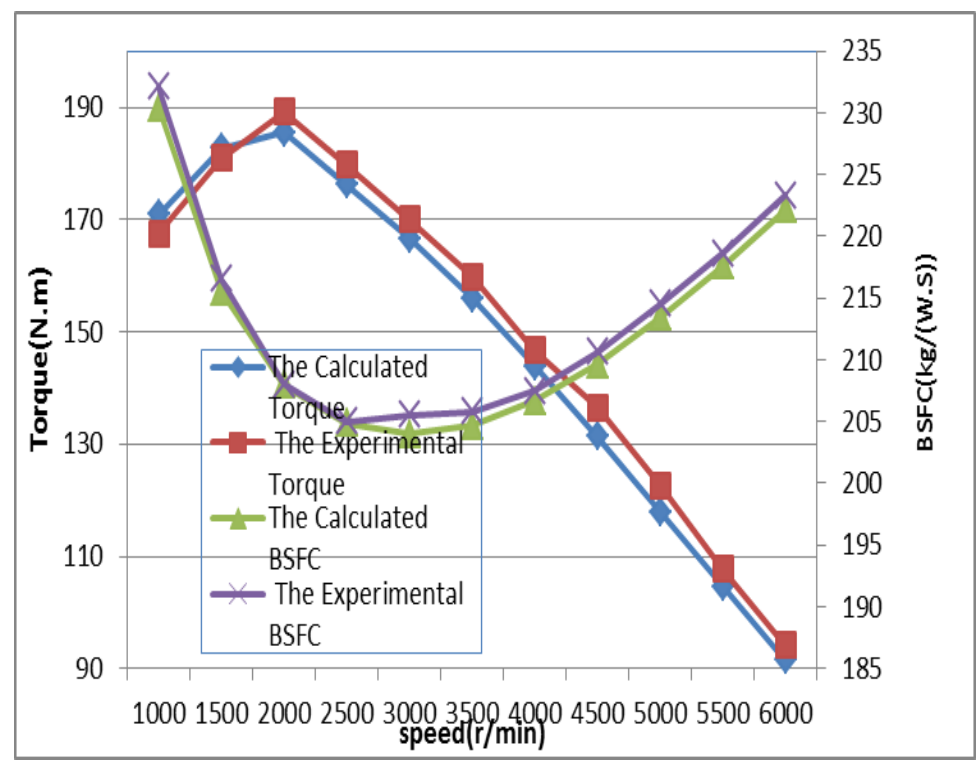

Figure 2. The calculated results compared with the experimental results

The comparative result shows that the relative deviation between simulation and experiment are both below $5 \%$.Therefor the simulation model of diesel engine established in this paper is accurate and reliable.

\section{Valve Timing Optimization Based on Response Surface Methodology}

\subsection{Response Surface Methodology}

Response Surface Methodology is a product with the development of statistics, mathematics and computer science. Experimenting, modeling, analyzing data, using graphics technology are used in order to show up the relationship of response system and we can know and select the optimized response of experiment design directly (Montgomery, 2007; Chen et al, 2009; Simate et al., 2009; Li et al., 2007; Liu, S. S. et al., 2012; Liu, C. et al., 2012). Response surface analysis of experiment includes Central Composite Design, Box-Behnken Design, Quadratic saturation D-optimal Design, Uniform Design, etc. Box-Behnken Design which can be called the efficiency design method, can be estimated in the Linear and Quadratic polynomial with the Linear interaction of polynomial model by fewer tests (Chen et al, 2009). The influence of valve timing on the volumetric efficiency of diesel engine under the rated speed is discussed and the response surface experiment is designed by using Box-Behnken Design. The test points and test data are showed in Tab.2. 
Table 2. Testing and test data of Box-Behnken design

\begin{tabular}{|c|c|c|c|c|c|}
\hline Std & IVO & IVC & EVO & EVC & volumetric efficiency \\
\hline 1 & 73 & 101 & 105 & 73 & 0.8231 \\
\hline 2 & 63 & 91 & 105 & 73 & 0.8066 \\
\hline 3 & 63 & 111 & 105 & 53 & 0.8466 \\
\hline 4 & 63 & 101 & 105 & 63 & 0.8400 \\
\hline 5 & 63 & 91 & 105 & 53 & 0.7903 \\
\hline 6 & 63 & 91 & 105 & 63 & 0.8400 \\
\hline 7 & 53 & 101 & 105 & 73 & 0.8496 \\
\hline 8 & 73 & 91 & 105 & 63 & 0.7896 \\
\hline 9 & 73 & 101 & 115 & 63 & 0.8264 \\
\hline 10 & 53 & 101 & 105 & 53 & 0.8268 \\
\hline 11 & 63 & 101 & 105 & 63 & 0.8400 \\
\hline 12 & 63 & 91 & 95 & 63 & 0.8034 \\
\hline 13 & 63 & 111 & 105 & 73 & 0.8606 \\
\hline 14 & 63 & 101 & 115 & 53 & 0.8216 \\
\hline 15 & 63 & 101 & 105 & 63 & 0.8400 \\
\hline 16 & 53 & 101 & 115 & 63 & 0.8481 \\
\hline 17 & 73 & 101 & 95 & 63 & 0.8252 \\
\hline 18 & 63 & 101 & 115 & 73 & 0.8441 \\
\hline 19 & 63 & 101 & 105 & 63 & 0.8400 \\
\hline 20 & 63 & 91 & 115 & 63 & 0.8090 \\
\hline 21 & 63 & 101 & 95 & 73 & 0.8432 \\
\hline 22 & 73 & 111 & 105 & 63 & 0.8469 \\
\hline 23 & 53 & 101 & 95 & 63 & 0.8444 \\
\hline 24 & 63 & 101 & 95 & 53 & 0.8258 \\
\hline 25 & 63 & 111 & 95 & 63 & 0.8576 \\
\hline 26 & 63 & 111 & 115 & 63 & 0.8628 \\
\hline 27 & 53 & 91 & 105 & 63 & 0.8120 \\
\hline 28 & 53 & 111 & 105 & 63 & 0.8632 \\
\hline 29 & 73 & 101 & 105 & 53 & 0.8115 \\
\hline
\end{tabular}

\subsection{The Analysis of Response Surface}

Design-Expert is a software which is used in optimized experiment by response surface widely. The equation of test response surface is some supposed. The hypothesis is: $\quad \mathrm{H}_{0}: \beta_{1}=\beta_{2}=\beta_{3}=\ldots=\beta_{\mathrm{i}}=0, \mathrm{H}_{1}: \beta_{1}, \beta_{2}, \beta_{3}, \ldots, \beta_{\mathrm{i}}$

Where: at least, one parameter is not equal to zero, and the significance level is $\alpha=0.05$.The "P value" is a concept which is the judgment instead of rejection region in statistics. The Box-Behnken Design of optimized analysis is used in this paper. The Tab.3 shows that the $\mathrm{P}$ values of $\mathrm{AC}, \mathrm{BC}, \mathrm{BD}, \mathrm{CD}$ and $\mathrm{C} 2$ are more than 0.05 , which indicates the terms in model are not notable, and need to be re-optimized.

Table 3. ANOVA for response surface quadratic model

\begin{tabular}{|c|c|c|c|c|c|}
\hline Source & Sun of Squares & $\mathrm{df}$ & Mean Square & F value & $\begin{array}{l}\text { P-value } \\
\text { Prob }>F\end{array}$ \\
\hline Model & 0.012 & 14 & 0.00083 & 344.14 & $<0.0001$ \\
\hline A-IVO & 0.00122 & 1 & 0.00122 & 504.82 & $<0.0001$ \\
\hline B-IVC & 0.00878 & 1 & 0.00878 & 3609.10 & $<0.0001$ \\
\hline C-EVO & 0.000012 & 1 & 0.000012 & 5.10 & 0.0038 \\
\hline D-EVC & 0.000945 & 1 & 0.000945 & 389.24 & $<0.0001$ \\
\hline $\mathrm{AB}$ & 0.000009 & 1 & 0.000009 & 3.82 & 0.0453 \\
\hline $\mathrm{AC}$ & 0.000001 & 1 & 0.000001 & 0.64 & 0.4363 \\
\hline $\mathrm{AD}$ & 0.000036 & 1 & 0.000036 & 2.44 & 0.00140 \\
\hline $\mathrm{BC}$ & 0.000001 & 1 & 0.000001 & 0.037 & 0.8502 \\
\hline $\mathrm{BD}$ & 0.000001 & 1 & 0.000001 & 0.0092 & 0.9247 \\
\hline $\mathrm{CD}$ & 0.000009 & 1 & 0.000009 & 2.67 & 0.1244 \\
\hline $\mathrm{A}^{2}$ & 0.000151 & 1 & 0.000151 & 62.07 & $<0.0001$ \\
\hline $\mathrm{B}^{2}$ & 0.000352 & 1 & 0.000352 & 145.02 & $<0.0001$ \\
\hline $\mathrm{C}^{2}$ & 0.000002 & 1 & 0.000002 & 1.50 & 0.2409 \\
\hline $\mathrm{D}^{2}$ & 0.000336 & 1 & 0.000336 & 138.22 & $<0.0001$ \\
\hline Residual & 0.000034 & 14 & 0.000002 & & \\
\hline Lack of Fit & 0.000034 & 10 & 0.000002 & & \\
\hline Pure Error & 0.000 & 4 & 0.000003 & \multirow{2}{*}{\multicolumn{2}{|c|}{$\mathrm{R}^{2}=0.9971$}} \\
\hline Cor Total & 0.012 & 28 & & & \\
\hline
\end{tabular}


The Tab. 4 shows that the $\mathrm{P}$ values of all are less than 0.05 , which indicates the terms in model are significant; then the response surface equation can be used. The response surface model equation is:

$$
\begin{aligned}
& \text { volumetriefficiency }=0.814-0.010 * A+0.027 * B+0.001017 * C \\
& +0.008883 * D+0.001525 * A * B-0.0028 * A * D-0.004967 A^{2} \\
& -0.007517 * B^{2}-0.007342 D^{2}
\end{aligned}
$$

\begin{tabular}{|c|c|c|c|c|c|}
\hline Source & Sum of Squares & $\mathrm{df}$ & Mean Square & F Value & p-value $\quad$ Prob $>F$ \\
\hline Model & 0.012 & 9 & 0.00130 & 538.74 & $<0.0001$ \\
\hline A-IVO & 0.00122 & 1 & 0.00122 & 508.82 & $<0.0001$ \\
\hline B-IVC & 0.00878 & 1 & 0.00878 & 3635.70 & $<0.0001$ \\
\hline C-EVO & 0.000012 & 1 & 0.000012 & 5.14 & 0.0038 \\
\hline D-EVC & 0.000945 & 1 & 0.000945 & 392.11 & $<0.0001$ \\
\hline $\mathrm{AB}$ & 0.000009 & 1 & 0.000009 & 3.85 & 0.0453 \\
\hline $\mathrm{AD}$ & 0.000031 & 1 & 0.000031 & 12.99 & 0.0019 \\
\hline $\mathrm{A}^{2}$ & 0.000166 & 1 & 0.000166 & 68.72 & $<0.0001$ \\
\hline $\mathrm{B}^{2}$ & 0.000380 & 1 & 0.000380 & 157.39 & $<0.0001$ \\
\hline $\mathrm{D}^{2}$ & 0.000362 & 1 & 0.000362 & 150.15 & $<0.0001$ \\
\hline Residual & 0.000034 & 19 & 0.000002 & & \\
\hline Lack of Fit & 0.000034 & 15 & 0.000002 & & \\
\hline Pure Error & 0.000 & 4 & 0.000 & & \\
\hline Cor Total & 0.012 & 28 & & $\mathrm{R}^{2}=0.9971$ & \\
\hline
\end{tabular}

Table 4. ANOVA for the optimized response surface quadratic model

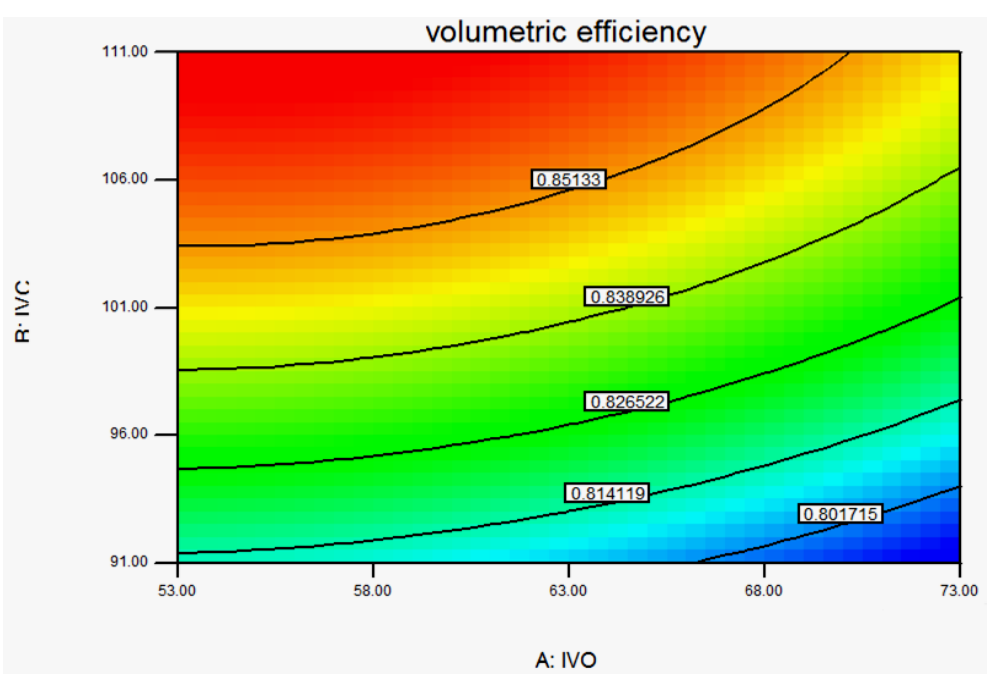

Figure 5(a). Contour plot of response surface methodology

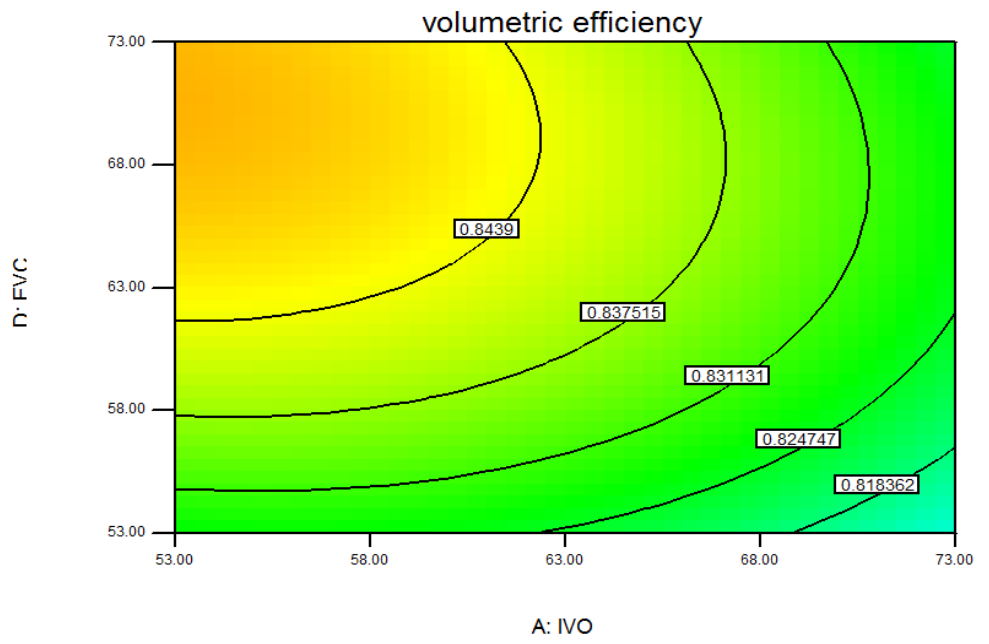

Figure 5(b). Contour plot of response surface methodology 


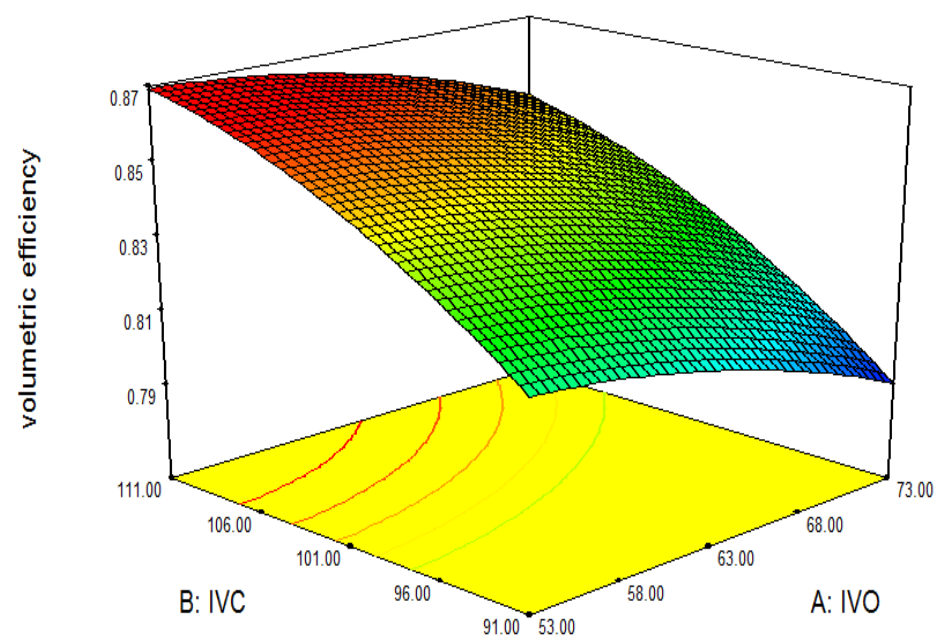

Figure 6(a). 3D surface of response surface methodology

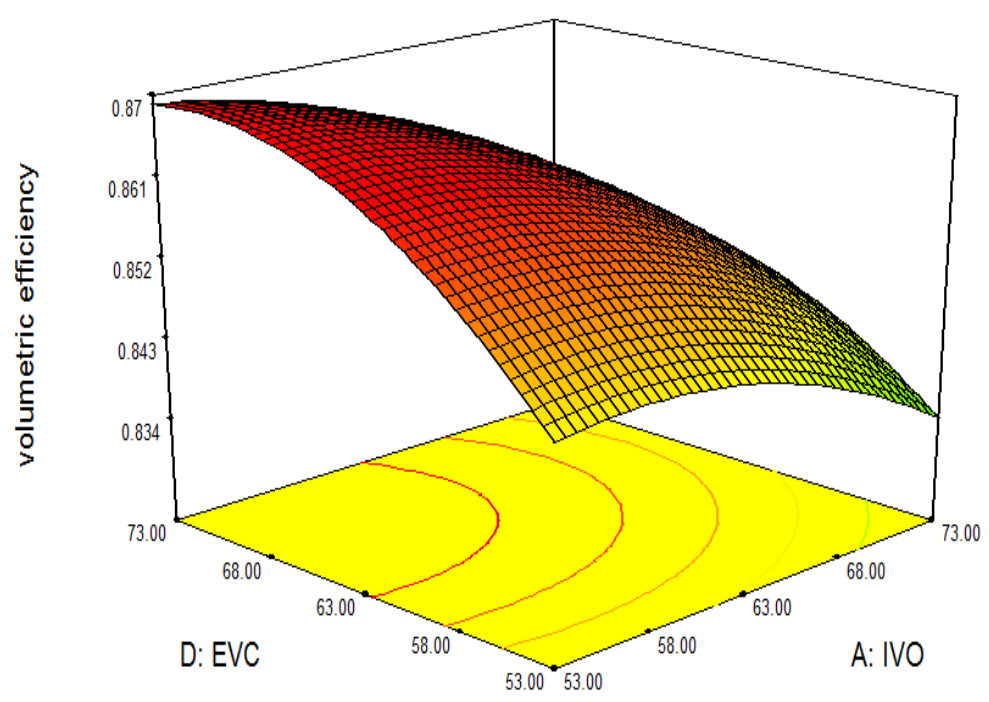

Figure 6(b). 3D surface of response surface methodology

The Fig.5 and Fig. 6 shows that: IVO is $53^{\circ} \mathrm{CA}$, IVC is $111^{\circ} \mathrm{CA}, \mathrm{EVO}$ is $115^{\circ} \mathrm{CA}, \mathrm{EVC}$ is $71^{\circ} \mathrm{CA}$.

\subsection{Verifying the Optimized Results of the Response Surface}

The optimal valve timing which is got from the response surface methodology is used to verify the simulation model. The Tab. 5 shows that the volumetric efficiency is increased by $6.42 \%$ after optimized.

Table 5. Volumetric efficiency contrast of before and after optimization

\begin{tabular}{cccccc}
\hline Type & $\mathrm{IVO}^{\circ} \mathrm{CA}$ & $\mathrm{IVC}^{\circ} \mathrm{CA}$ & $\mathrm{EVO}^{\circ} \mathrm{CA}$ & $\mathrm{EVC}^{\circ} \mathrm{CA}$ & volumetric efficiency \\
\hline Original & 63 & 101 & 105 & 63 & 0.841 \\
Optimization & 53 & 111 & 115 & 71 & 0.895 \\
\hline
\end{tabular}

\section{Conclusions}

1) Based on the response surface methodology, we can optimize the volumetric efficiency and valve timing of diesel engine, establish the response surface quadratic model, draw the 3D surface of response surface methodology and then can carry out the optimization and interaction between volumetric efficiency and valve timing.

2) Getting the valve timing of the diesel engine from the response surface methodology, analyzed the simulation model of the diesel engine. The results show that the volumetric efficiency can be optimal value under the rated speed. 


\section{Acknowledgements}

This project is supported by National Natural Science Foundation of China (No. 51305472) and Education and Teaching Reform Project of Chongqing CSTC, China (KJ090408; No.0903070)

\section{References}

Chen, X. K., Li, B. G., \& Lin, Y. (2009). Application of Improved RSM in the Optimization Design of Automotive Frontal Crashworthiness. Transaction of Beijing Institute of Technology, 1076-1077. http://lib.cqvip.com/read/detail.aspx ?ID=32654508

Lei, J. L., Huang, Z. P., Shen, L. H., et al. (2011). Working Process Simulation and Performance Optimization of High-pressure Common Rail Diesel Engine. Vehicle Engine, 53-57. http://202.202.244.3/kns50/detail.aspx?QueryID=27\&CurRec=1

Li, J., \& Liang, X. G. (2007). Scramjet Inlet Multi-Objective Optimization Based on response surface methodology. Transactions of Nanjing University of Aeronautics \& Astronautics, 205-209. http://en.cnki.com.cn/Article_en/CJFDTOTAL-NJHY200703006.htm

Liu, C., Pan, X., Yan, Q. D., et al. (2012). Effect of Blade Number on Performance of Torque Converter and Its Optimization Based on DOE and Response Surface Methodology. Transaction of Beijing Institute of Technology, 689-693. http://lib.cqvip.com/qk/95548X/201207/43098212.html

Liu, F. F., Jiang, C. H., \& Xia, X. L. (2011). Effect on Performance of Gasoline Engine about Intake Valve Closing Angle. Journal of Nanchang University (Engineering \& Technology), 66-68. http://lib.cqvip.com/read/detail.aspx?ID=37154422

Liu, S. S., Gu, Z. Q., Wu, W. G., et al. (2012). Multi-objective Collaborative Optimization of Vehicle Based on Response Surface Methodology. Journal of Central South University (Science and Technology), 2586-2591. http://lib.cqvip.com/qk/90745B/201207/42974900.html

Montgomery, D. C. (2007). Design and Analysis of Experiments, 6th Ed. New York: 404-406.

Rakopoulos, C. D., Giakoumis, E. G., Hountalas, D. T., et al. (2004). The Effect of Various Dynamic, Thermodynamic and Design Parameters on the Performance of a Turbocharged Diesel Engine Operating under Transient Load Conditions. SAE Paper. http://papers.sae.org/2004-01-0926/

Razmjooei, K., \& Nagarajan, G. (2010). Optimization of DI Diesel Engine Operating Parameters Using a Response Surface Method. SAE Paper. http://papers.sae.org/2010-01-1262/

Simate, G. S., Ndlovu, S., \& Gericke, M. (2009). Bacterial leaching of nickel laterite using chemolithotrophic microorganisms: Process optimization using response surface methodology and central composite rotatable design. Hydrometallurgy, 4(3), 241-243. http://www.sciencedirect.com/science/article/pii/S0304386X09001236

\section{$(\mathrm{cc}) \mathrm{Br}$}

This work is licensed under a Creative Commons Attribution 3.0 License. 